Serambi Saintia

\title{
Pengukuran Faktor yang Mempengaruhi Kepatuhan Akseptor KB Suntik Ulang 1 Bulan
}

\author{
Lia Muslima ${ }^{1}$ \\ Herjanti $^{2}$ \\ ${ }^{1}$ D-III Kebidanan STIKes Payung Negeri Aceh Darussalam Bener Meriah \\ ${ }^{2}$ Sekolah Tinggi Ilmu Kesehatan Indonesia Maju \\ Email: liamuslima91@gmail.com
}

\begin{abstract}
ABSTRAK
Kepatuhan terbentuk melalui nilai-nilai ketaatan, kesetiaan, keteraturan dan ketertiban dalam hal ini yaitu ketaatan seorang akseptor dalam penyuntikan KB ulang cyclofem sesuai jadwal.Penelitian ini bertujuan untuk mengetahui pengaruh langsung dan tidak langsung serta besaran antara peran bidan, peran suami, persepsi dan pemanfaatan pelayanan kesehatan terhadap kepatuhan akseptor KB suntik ulang 1 bulan di BPM Sari Mulyani Cililitan Jakarta Timur.Populasi penelitian ini adalah seluruh akseptor KB suntik ulang 1 bulan di BPM Sari Mulyani. Desain penelitian ini menggunakan pendekatan cross sectional.Sampel dalam penelitian ini sebanyak 45 responden. Penelitian ini menggunakan analisis Structural Equating Modelling (SEM). Pengumpulan data dilakukan dengan cara membagikan kuesioner. Hasilnya menunjukkan kepatuhan akseptor KB dipengaruhi oleh peran bidan $(15,6 \%)$, peran suami $(27,3 \%)$, persepsi $(16,7 \%)$ dan pemanfaatan pelayanan kesehatan $(40,8 \%)$. Hasil penelitian ini mampu menjelaskan $99 \%$ keragaman data pada fenomena penelitian yang serupa.
\end{abstract}

Kata kunci : Bidan, Suami, Persepsi, Pelayanan, Kepatuhan.

\section{PENDAHULUAN}

Berdasarkanlaporan World Health Organization (WHO) pada tahun 2012, angka pengguna kontrasepsi diperkirakanmencapai 460 juta jiwa, atau sekitar 51\% dari pasangan yang beresiko hamil. Dari data tersebut, sekitar $21 \%$ penduduk menggunakan metode kontrasepsi suntik. Berdasarkan data Badan Kependudukan dan Keluarga Berencana Nasional (BKKBN), di Indonesia pada tahun 2013 tercatat angka prevalensi peserta KB aktif sudah melebihi target SPM (Standar Pelayanan Minimal) tahun 2014 sebesar 65\%, walaupun mengalami sedikit penurunan dari 82,07\% pada tahun 2012 menjadi 80,98\% pada tahun 2013 dengan komposisi penggunaan alat kontrasepsi jangka pendek terutama suntik masih mendominasi. Di Jawa Timur tahun 2013 tercatat akseptor KB sejumlah 100.594 akseptor (BKKBN, 2012.).

Negara Indonesia berada di urutan ke-4 penduduk terbanyak di dunia setelah Cina, India dan Amerika. Sensus penduduk Indonesia 2013 menunjukkan jumlah penduduk Indonesia 237.641.326 jiwa. Jumlah penduduk di provinsi DIY mencapai 3637,1 jiwa penduduk yaitu terbagi antara laki-laki terdapat 1797,4 jiwa penduduk sedangkan untuk perempuan terdapat 1839,7 jiwa penduduk. Jumlah penduduk di 


\section{Lia Muslima, dan Herjanti}

Kabupaten Bantul pada tahun 2014 mencapai 947.066 jiwa penduduk yang terdiri dari laki-laki 465.981 jiwa penduduk sedangkan untuk perempuan mencapai 477.085 jiwa penduduk, dengan laju pertumbuhan penduduk 0,96 pertahun. Bantul termasuk kabupaten yang memiliki laju pertumbuhan penduduk yang cukup besar dan kepadatan penduduk yang tinggi yaitu mencapai 2,994 jiwa (BKKBN. 2012b).

Di Indonesia metode kontrasepsi suntik merupakan metode yang paling banyak diminati. Secara nasional pada Oktober 2013 ada sebanyak 723.456 (Kemenkes, 2013). Upaya untuk mengatasi ledakan jumlah penduduk tersebut salah satunya adalah melalui program Keluarga Berencana (KB). KB merupakan bagian integral dari pembangunan nasional yang bertujuan melembagakan Norma Keluarga Kecil Bahagia dan Sejahtera (NKKBS). KB adalah tindakan yang membantu individu atau pasangan suami istri untuk mendapatkan objek-objek tertentu, menghindari kelahiran yang tidak diinginkan, mendapatkan kelahiran yang memang diinginkan, mengatur interval diantara kehamilan, mengontrol waktusaat-saat kelahiran dalam hubungan dengan umur suami istri, dan untuk menentukan jumlah anak dalam keluarga.

Berdasarkan hasil Survei Demografi dan Kesehatan Indonesia (SDKI)2012 menunjukkan, tingkat prevelensi pemakaian alat kontrasepsi atau Contraceptive Prevalance Rate (CPR) yang menunjukkan tingkat kesertaan ber-KB di antara pasangan usia subur mencapai $61,9 \%{ }^{4}$ Sebanyak $57,9 \%$ menggunakan cara KB modern yang hanya meningkat $0,5 \%$ dari $57,4 \%$ dalam lima tahun terakhir. Dari data tersebut dihasilkan bahwa penggunaan kontrasepsi terbanyak adalah kontrasepsi suntik, yaitu sebanyak 22,14\% (BPS, 2013). Sedangkan di Temanggung pada tahun 2013 yang menggunakan kontrasepsi IUD sebesar 13,64\%, menggunakan MOP sebesar 0,25\%, menggunakan MOW sebesar 2,97\%, menggunakan implant sebesar 45,39\%, menggunakan suntik sebesar 31,47\%, menggunakan pil sebesar 4,03\%, dan yang menggunakan kondom sebesar 2,24\% (Kemenkes, 2013).

Akseptor KB baru secara nasional sampai dengan Desember 2012 sebanyak 9.388.374 akseptor. Prosentasenya adalah sebagai berikut : 706.102 akseptor IUD (7,52\%) 131.053 akseptor MOW (1,40\%), 27.680 akseptor MOP (0,29\%), 766.461 akseptor kondom $(8,16 \%), 806.532$ akseptor Implant (8,59\%), 4.406 .898 akseptor suntikan (46,94\%), dan 2.543.648 akseptor Pil (27,09\%). ${ }^{5}$ Target cakupan layanan KB yang ditetapkan pemerintah Indonesia yang terangkum dalam indikasi keberhasilan program Millenium Development Goals (MDG's) yaitu sebesar 70\% . Sasaran utama kinerja program KB adalah menurunnya Pasangan Usia Subur (PUS) yang ingin melaksanakan $\mathrm{KB}$ namun pelayanan $\mathrm{KB}$ tidak terlayani (unmet need) menjadi sekitar $6,5 \%$, meningkatnya partisipasi laki-laki dalam melaksanakan KB menjadi sekitar $8 \%$, menurunnya angka kelahiran total (TFR) menjadi 2,4\% per perempuan (BKKBN, 2010).

Kontrasepsi hormonal jenis KB suntikan ini di Indonesia semakin banyak dipakai karena kerjanya yang efektif, pemakaiannya yang praktis, harganya relatif murah dan aman. Kontrasepsi suntik memiliki resiko kesehatan yang sangat kecil, tidak berpengaruh pada hubungan suami-istri. Keuntungan atau manfaat kontrasepsi suntik diantaranya tidak memerlukan pemeriksaan dalam, klien tidak perlu menyimpan obat, jangka panjang dan efek sampingnya sangat kecil.Kepatuhan yang dimiliki para akseptro KB khususnya akseptor KB suntik, pada dasarnya dipengaruhi oleh kesadaran dari pemakai serta dukungan keluarga, terutama suami yang mana dapat menjadi suati motivasi bagi akseptor suntik. Berdasarkan hasil studi pendahuluan yang dilakukan Ida 
Rafidah 2010, didapatkan hasil 6 orang (60\%) tidak adanya peran suami untuk kunjungan ulang KB suntik.

Dampak ketidakpatuhan mengunakan akseptor $\mathrm{KB}$ suntik memungkinkan akseptor mengalami kehamilan. Hal ini dikarenakan hormon yang terkandung dalam KB suntik tidak bisa bekerja dengan maksimal. Sehingga memungkinkan akseptor KB suntik mengalami kehamilan yang tidak diinginkan. Kondisi ini bisa membuat akseptor KB suntik panik sehingga melakukan tindakan pengguguran kandungan yang beresiko tinggi, seperti aborsi. Penelitian oleh Aryani yang berjudul "Peran Bidan Dalam Konseling Awal Kontrasepsi Suntik Cyclofem di Puskesmas Mergangsan, Yogyakarta Tahun 2012".Hasil penelitian menunjukkan bahwa peran bidan dalam konseling awal kontrasepsi cyclofem. Kategori baik adalah 71,1\% kategori cukup 21,7\% dan ketegori kurang 7,2\% (Aryani, 2010).

Penelitian oleh Adriana Nara berjudul "Hubungan Pengetahuan, Sikap, Akses Pelayanan Kesehatan, Jumlah Sumber Informasi Dan Dukungan Keluarga Dengan Pemanfaatan Pelayanan Kesehatan Yang Memadai di Puskesmas Kawangu Kabupaten Sumba Timur Tahun 2013". Hasil uji bivariat diketahui ada hubungan pengetahuan ibu bersalin $(\mathrm{p}=0,001)$, sikap $(\mathrm{p}<0,001)$, akses pelayanan kesehatan $(\mathrm{p}<0,001)$, jumlah informasi $(\mathrm{p}=0,039)$, dukungan keluarga $(\mathrm{p}<0,001)$ dengan pemanfaatan fasilitas persalinan yang memadai. Pada analisis multivariat, variabel yang berhubungan dengan pemanfaatan fasilitas persalinan yang memadai adalah akses pelayanan kesehatan dengan $p=0,018 ; \mathrm{OR}=11,679 ; \mathrm{CI} 95 \%=1,365-99,891$ (Adriana Nara, 2013).

Berdasarkandiketahui jumlah akseptor kontrasepsi di BPM Sari Mulyani pada tahun 2016 sebanyak 831 akseptor, pemakaian kontrasepsi terbesar yaitu KB suntik sebanyak 737 akseptor (88,7\%), PIL sebanyak 89 akseptor (10,7\%), IUD sebanyak 3 akseptor $(0,4 \%)$ dan impant sebanyak 2 akseptor $(0,2 \%)$. Untuk akseptor yang ingin MOW dan MOP, BPM Sari Mulyani melakukan rujukan ke Rumah Sakit Restu Kasih Cililitan Kramat Jati, dimana setiap akseptor mendapat layanan gratis untuk tindakan tersebut dan layanan gratis untuk MOW dan MOP ini bekerja sama dengan BKKBN pusat.Sedangkan metode KB seperti kondom, MAL, pantang berkala dan senggama terputus tidak dilakukan pendokumentasian atau pendataan di BPS Sari Mulyani.

Penelitian ini dilakukan untuk mengetahui adanya pengaruh langsung dan tidak langsung serta besaran antara peran bidan, peran suami, persepsi dan pemanfaatan pelayanan kesehatan terhadap kepatuhan akseptor KB suntik ulang 1 bulan di BPM Sari Mulyani tahun 2017.

\section{METODE PENELITIAN}

Penelitian ini dilakukan pada Februari 2017. Tempat penelitian di BPM Sari Mulayni Cililitan. Populasi penelitian ini ialahseluruh akseptor KB suntik 1 bulan yang melakukan penyuntikan KB ulang di BPM Sari Mulyani Cililitan Tahun 2017 yang berjumlah 80 orang. Penentuan jumlah sampel menggunakan rumus rule of thumb, sehingga diperoleh jumlah sampel dalam penelitian 45 akseptor KB suntik 1 bulan. Instrumen pada penelitian ini angket atau kuisioner. Pada tahap pengujian kedua pengujian bivariat, digunakan pengujian chi square dengan tingkat signifikasi $\alpha=5 \%$ dan hasinya pada setiap variabel menunjukkan nilai $p$ value> 0,005. Hal ini menunjukkan bahwa variabel penelitian tidak ada yang berhubungan dengan karakteristik responden. 
Lia Muslima, dan Herjanti

Jumlah kelas untuk mendekripsikan jawaban responden menggunakan rumus Struges sehingga didapat hasil 7 kelas. Didapatkan bahwa jawaban 45 responden tentang variabel kepatuhan sebagian besar berada direntang aktual 59-66 (24,4\%), variabel peran suami berada direntang aktual 51-55 (28,9\%), variabel persepsi sebagian besar berada direntang aktual 63-68 (28,9\%) dan variabel pemanfaatan pelayanan kesehatan sebagian besar berada direntang aktual 43-46 (22,2\%).Kriteria Eksklusi adalah menghilangkan atau mengeluarkan subjek yang memenuhi kriteria inklusi dari studi karena suatu berbagai sebab seperti: Pasien akseptor KB yang tidak hadir saat penyebaran kuesioner dan pasien yang suntik KB berpindah-pindah dalam memilih metode kontrasepsi lain. ${ }^{8}$

Metode pengukuran menggunakan skala interval, tehnik pengukurannya menggunakan smantic differential, dengan skala 5 poin. Dalam penelitian ini menggunakan variabel laten independen dan dependen (Nursalam, 2011). Data dianalisis dengan StructuralEquation Modeling (SEM).

\section{HASIL PENELITIAN DAN PEMBAHASAN Hasil Penelitian}

Hasil penelitian disusun berdasarkan sistematika yang dimulai dengan gambaran analisis univariat yang dilanjutkan dengan analisa bivariate dan diakhiri dengan gambaran analisis SEM.

Hasil analisis pengolahan data Nilai probablility pada analisis ini menunjukkan nilai batas signifikansi yaitu 0,05 . Dari hasil pengolahan data jugaterlihat bahwa setiap indikator atau dimensi pembentuk variabel laten konstruk peran bidan, peran suami, persepsi dan pemanfaatan pelayanan kesehatan dan kepatuhan akseptor KB suntik ulang 1 bulan tersebut telah menunjukkan hasil yang baik.

Berdasarkan tabel 1 dari 45 responden dapat dilihat untuk umur akseptor $\mathrm{KB}$ suntik terbanyak berada pada kelompok akseptor umur 20 - 35 tahun yaituresponden $(75,6 \%)$ dan dilihat berdasarkan tingkat pendidikan mayoritas responden berpendidikan sebanyak responden $(48,9 \%)$ sedangkan berdasarkan status pekerjaan, mayoritas responden bekerja sebanyak responden $(68,9 \%)$ akseptor KB suntik yang memiliki pekerjaan yaitu 16 responden $(53,3 \%)$.

Berdasarkan table 1 dapat dilihat semua variabel dinyatakan valid karena memberikan nilai 0,5 sehingga dapat disimpulkan bahwa evaluasi pengukuran model memiliki discriminant validityyang baik atau valid. Metode lain untuk menilai discriminant validityadalah membandingkan nilai square root of average variance extracted $(A V E)$ setiap konstruk dengan konstruk lainnya dalam model maka dikatakan memiliki nilai discriminant validityyang baik.

Tabel 1 menyatakan secara lengkap deskripsi karakteristik responden disajikan dalam bentuk sebagai berikut: 
Serambi Saintia

Volume VII, No.1, April 2019

Jurnal Sains dan Aplikasi
pISSN $2337-9952$

eISSN $2656-8446$

Tabel 1 Distribusi Responden Menurut Karakteristik, 2017

\begin{tabular}{ccccc}
\hline No & \multicolumn{2}{c}{ Karakteristik } & N & $\mathbf{( \% )}$ \\
\hline 1 & Umur & $<20^{\mathrm{Th}}$ & 5 & 11,1 \\
& & $20-35 \mathrm{Th}$ & 34 & 75,6 \\
& & $>35 \mathrm{Th}$ & 6 & 13,3 \\
2 & \multirow{2}{*}{ Pendidikan } & SD & 6 & 13,3 \\
& & SMP & 13 & 28,9 \\
& & SMA & 22 & 48,9 \\
& & Perguruan & 4 & 8,9 \\
& & Tinggi & & \\
3 & \multirow{2}{*}{ Pekerjaan } & Tdk Bekerja & 14 & 31,1 \\
& & Bekerja & 31 & 68,9 \\
\hline
\end{tabular}

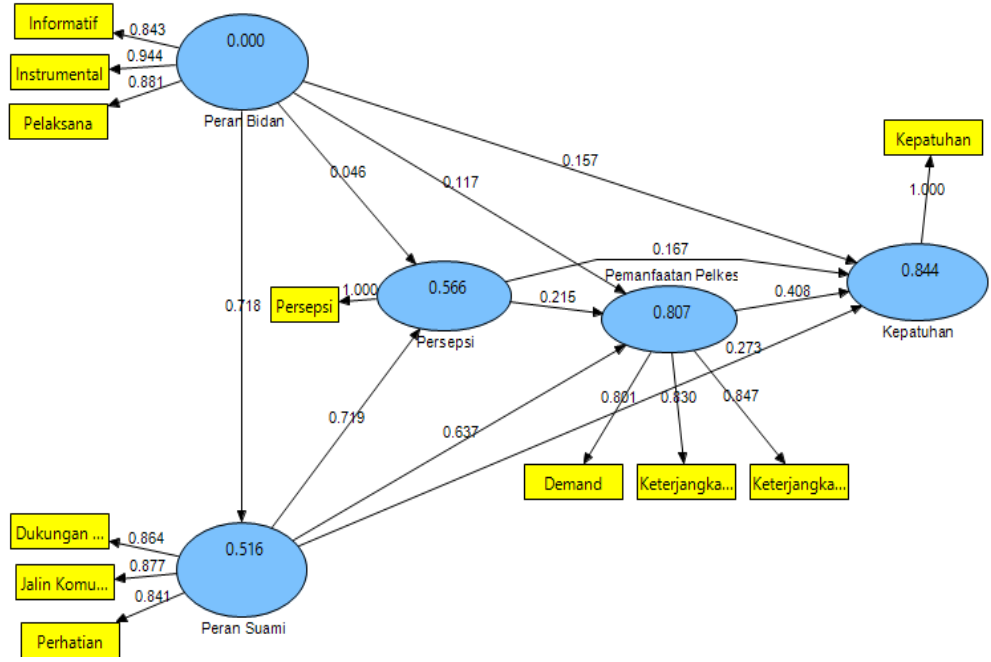

Gambar 1.Output PLS (Loading Factor)

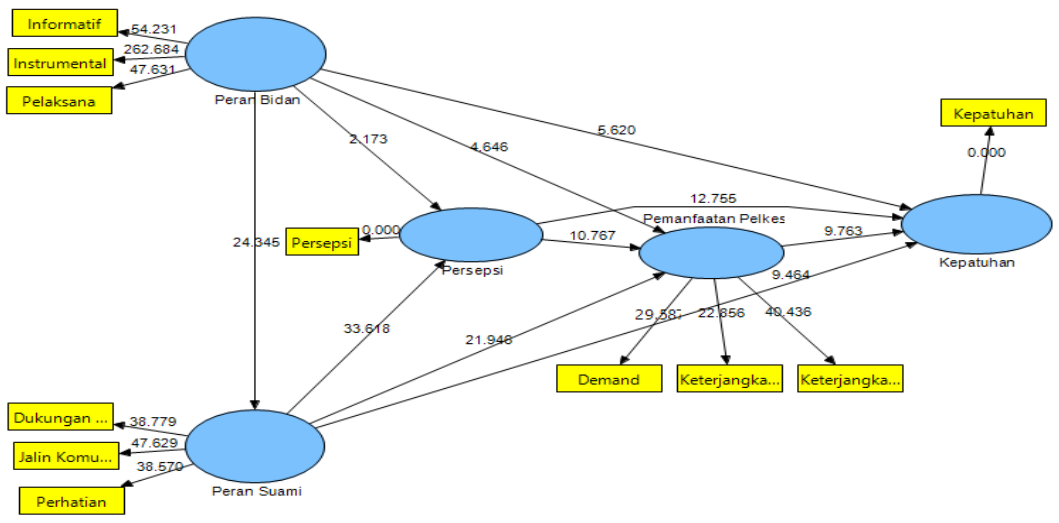

Gambar 2.Output PLS (T Statistic) 
Lia Muslima, dan Herjanti

\section{Evaluasi Inner Model}

Berdasarkan gambar 2 menyatakan bahwa nilai hasil $T$ statistic direfleksikan terhadap variabelnya sebagian besar $>1,96$ sehingga menunjukkan suatu blok indikator berpengaruh positif dan signifikan untuk merefleksikan variabelnya. Selanjutnya dilakukan uji inner model terhadap model structural dilakukan dengan melihat $R$ square yang merupakan uji yang sedang dikaji dan hasilnya sebagai berikut:

\section{Tabel 2.Evaluasi Nilai $R$ Square}

\begin{tabular}{lc} 
Variabel & RSquare \\
\hline Kepatuhan & 0,843672 \\
Peran Bidan & \\
Peran Suami & 0,515663 \\
Persepsi & 0,566125 \\
Pemanfaatan PelKes & 0,807213 \\
\hline
\end{tabular}

Sumber: Output PLS, 2017

Berdasarkan output smartPLS nilai $R$ square untuk variabel kepatuhan adalah 0,8436 yang artinya variabel peran bidan mampu menjelaskan terhadap variabel kepatuhan sebesar $84 \%$ dan sisanya sebesar $16 \%$ di jelaskan oleh variabel lain diluar dari yang diteliti. Nilai $\mathrm{R}$ square variabel persespsi adalah 0,5661yang artinya variabel peran bidan mampu menjelaskan terhadap variabel persepsi sebesar 56,6\% dan sisanya sebesar $43 \%$ di jelaskan oleh variabel lain diluar dari yang diteliti. Nilai Rsquare variabel peran suami adalah 0,5156 yang artinya variabel peran bidan mampu menjelaskan terhadap variabel peran suami sebesar 51,5\% dan sisanya sebesar $48 \%$ di jelaskan oleh variabel lain dari yang diteliti. Nilai dari $R$ squarevariabel pemanfaatan pelayanan kesehatan adalah 0,8072 yang artinya variabel peran bidan mampu menjelaskan terhadap variabel pelayanan kebidanan sebesar $80,7 \%$ dan sisanya sebesar $19 \%$ dijelaskan oleh variabel lain diluar dari yang diteliti. Dari $R$ square tersebut dapat dinyatakan bahwa variabel kepatuhan akan di pengaruhi oleh variabel peran bidan, peran suami, persepsi dan pemanfaatan pelayanan kesehatan sebesar $84 \%$. Sembilanhubungan variabel yang nilai t statistiknya $>1,96$, yaitu Sembilan nilai $T$ statistic berada jauh besar di nilai kritis 1,96. Peran bidan berpengaruh positif terhadap kepatuhan dengan hasil uji terhadap koefisien 0,1569 , sedangkan nilai $T$ statistic30,9521dan signifikan pada $\alpha=5 \%$, nilai tersebut berada lebih dari $(1,96)$.

Peran bidan berpengaruhpositif terhadap persepsi dengan hasil uji terhadap koefisien 0,0458 , sedangkan nilai $T$ statistic 17,9779 dan signifikan pada $\alpha=5 \%$, nilai tersebut berada lebih dari $(1,96)$. Peran bidan berpengaruh positif terhadap pemanfaatan pelayanan kesehatan dengan hasil uji terhadap koefisien 0,1173 , sedangkan nilai $T$ statistic26,0840dan signifikan pada $\alpha=5 \%$, nilai tersebut berada lebih dari $(1,96)$. Peran bidan berpengaruh positif terhadap peran suami dengan hasil uji terhadap koefisien 0,7180 , sedangkan nilai $T$ statistic 25,9753 dan signifikan pada $\alpha=5 \%$, nilai tersebut berada lebih dari $(1,96)$.

Persepsi berpengaruh positif terhadap kepatuhandengan hasil uji terhadap koefisien 0,1607, sedangkan nilai $T$ statistic 14,6771 dan signifikan pada $\alpha=5 \%$, nilai tersebut 
berada lebih dari $(1,96)$. Persepsi berpengaruh positif terhadap pemanfaatanpelayanan kesehatan dengan hasil uji terhadap koefisien 0,2149, sedangkan nilai $T$ statistic 8,8541 dan signifikan pada $\alpha=5 \%$, nilai tersebut berada lebih dari $(1,96)$

Selanjutnya pada pemanfaatan pelayanan kesehatan berpengaruh positif terhadap kepatuhan dengan hasil uji terhadap koefisien 0,4083, sedangkan nilai $T$ statistic 9,9801 dan signifikan pada $\alpha=5 \%$, nilai tersebut berada lebih dari $(1,96)$.

Pada peran suami berpengaruh positif terhadap kepatuhan dengan hasil uji terhadap koefisien 0,2733, sedangkan nilai $T$ statistic27,1103dan signifikan pada $\alpha=5 \%$, nilai tersebut berada lebih dari $(1,96)$. Peran suami berpengaruh positif terhadap persepsi dengan hasil uji terhadap koefisien 0,7188, sedangkan nilai $T$ statistic28,3307dan signifikan pada $\alpha=5 \%$, nilai tersebut berada lebih dari $(1,96)$.

Berdasarkan pola hubungan antarvariabel yang telah digambarkan dalam kerangka konsep, ada hubungan yang bersifat langsung dan tidak langsung yang dijabarkan seperti tabel.

Berdasarkan tabel 3 menyatakan bahwa hasil uji terhadap koefisien parameter antara peran bidan terhdap kepatuhan menunjukkan pengaruh langsung sebesar $11,47 \%$, sedangkan untuk pengaruh tidak langsung variabel peran bidan terhadap variabel kepatuhan sebesar 0,8606\% dengan mengalikan koefisien jalur (peran bidan mempengaruhi peran suami, peran suami mempengaruhi variabel kepatuhan) koefisien jalur (peranbidan mempengaruhi peran suami, peran suami mempengaruhi persepsi, persepsi mempengaruhi kepatuhan koefisien jalur (peran bidan mempengaruhi pemanfaatan pelayanan kesehatan, pemanfaatan pelayanan kesehatan mempengaruhi kepatuhan), koefisien jalur (peran bidan mempengaruhi persepsi, persepsi mempengaruhi kepatuhan) dan koefisien jalur (peran bidan mempengaruhi pemanfaatan pelayanan kesehatan, pemanfaatan pelayanankesehatan mempengaruhi persepsi, dan variabel persepsi mempengaruhi kepatuhan.

Hasil uji terhadap koefisien parameter antara variabel pemanfaatan pelayanan kesehatan terhadap kepatuhan yang menunjukkan pengaruh langsung sebesar 36,17\%dengan mengalihkan koefisien jalur (pelayanan kebidanan mempengaruhi persepsi, persepsi mempengaruhi kepatuhan). Hasil uji terhadap koefisien parameter antara variabel persepsi terhadap variabel kepatuhan yang menunjukkan pengaruh langsung sebesar $12,87 \%$ sedangkan untuk pengaruh tidak langsung persepsiterhadap kepatuhan sebesar 0,49\%.

Hasil uji terhadap koefisien parameter antara variabel peran suami terhadap kepatuhan menunjukkan pengaruh langsung sebesar $23,48 \%$, sedangkan untuk pengaruh tidak langsung peran suami terhadap kepatuhan sebesar 1,68\% dengan mengalikan koefisien jalur (peransuami mempengaruhi persepsi, dan variabel persepsi mempengaruhi kepatuhan).Hasil uji terhadap koefisien parameter antara variabel persepsi terhadap variabel kepatuhan yang menunjukkan pengaruh langsung sebesar $12,87 \%$ sedangkan untuk pengaruh tidak langsung persepsiterhadap kepatuhan sebesar $0,49 \%$. Hasil uji terhadap koefisien parameter antara variabel pemanfaatan pelayanan kesehatan terhadap kepatuhan. Berdasarkan pola hubungan antarvariabel yang telah digambarkan dalam kerangka konsep, ada hubungan yang bersifat langsung dan tidak langsung yang dijabarkan seperti tabel.

Sehingga nilai masing-masing pengaruh langsung variabel laten independent tersebut apabila secara bersama-sama menunjukkan kesesuaian dengan nilai $R$ Square 
Lia Muslima, dan Herjanti

atau dengan kata lain hal ini menyatakan bahwa variabel peran bidan, peran suami, pemanfaatan pelayanan kesehatan dan persepsi mampu menjelaskan variabel kepatuhan $84,36 \%$.

Tabel 3.Persentase Pengaruh Antar Vatiabel terhadap Variabel Kepatuhan Akseptor KB Suntik Ulang 1 Bulan

\begin{tabular}{lccccccc}
\hline \multicolumn{1}{c}{ Variabel } & $\begin{array}{c}\text { LVCorelatio } \\
\boldsymbol{n}\end{array}$ & $\begin{array}{c}\text { Direct } \\
\text { Path }\end{array}$ & $\begin{array}{c}\text { Inderect } \\
\text { Path }\end{array}$ & Total & $\begin{array}{c}\text { Direct } \\
\text { \% }\end{array}$ & Indirect\% & Total\% \\
\hline Peran Bidan & 0,7311 & 0,1569 & 0,5742 & 0,7311 & 11,4747 & 0,8606 & 12,3353 \\
Peran Suami & 0,8721 & 0,2733 & 0,4432 & 0,7166 & 23,481 & 1,6856 & 25,5275 \\
Persepsi & 0,7709 & 0,1670 & 0,0049 & 0,1719 & 12,877 & 0,4922 & 13,3701 \\
Pem. Pelkes & 0,8857 & 0,4083 & & 0,4083 & 36,1719 & & 36,1719 \\
\hline \multicolumn{3}{c}{ Total } & & & 84,3665 & 3,0385 & 87,4050 \\
\hline
\end{tabular}

Sumber:Output PLS, 2017.

Berdasarkan analisa di atas didapatkan persamaan matematis:

$$
\eta 1=\gamma 1 \varepsilon_{0} 1+\zeta 1
$$

(Peran Suami $=0,718$ peran bidan $+0,282$ faktor lain), berarti peran suami dipengaruhi oleh peran bidan sebesar 0,718 dan sisanya $2,82 \%$ dipengaruhi faktor lain sesuai teori seperti pendidikan, bentuk keluarga dan latar belakang keluarga.

$$
\boldsymbol{\eta} 2=\boldsymbol{\gamma} \mathbf{3} . \boldsymbol{\xi}+\boldsymbol{\beta 1} \mathbf{1} \mathbf{1} 1+\boldsymbol{\zeta} \mathbf{2}
$$

(Persepsi $=0,046$ peran bidan $+0,719$ peran suami $+0,235$ faktor lain)pada variabel persepsi dipengaruhi oleh pemanfaatan pelayanan kesehatan sebesar 0,046 , peran suami sebesar 0,719 dan sisanya $23,5 \%$ dipengaruhi faktor lain.

$$
\boldsymbol{\eta} \mathbf{3}=\gamma_{\mathbf{3}} \boldsymbol{\xi} \mathbf{1}+\boldsymbol{\beta}_{\mathbf{3}} \mathbf{\eta}_{\mathbf{1}}+\boldsymbol{\beta}_{\mathbf{4}} \mathbf{\eta}_{\mathbf{2}}+\boldsymbol{\zeta}_{\mathbf{3}}
$$

(pemanfaatan pelayanan kesehatan $=0,117$ peran bidan $+0,637$ peran suami +0.125 persepsi $+0,969$ faktor lain) pada variabel pemanfaatan pelayanan kesehatan di pengaruhi oleh peran bidan sebesar 0,117 peran suami sebesar 0.203 dan pelayanan kebidanan sebesar 0,637dan persepsi 0,215 dan sisanya dipengaruhi faktor lain sebesar $96,9 \%$.

$$
\boldsymbol{\eta} \mathbf{4}=\boldsymbol{\gamma}_{\mathbf{4}} \boldsymbol{\xi} \mathbf{1}+\boldsymbol{\beta}_{\mathbf{2}} \boldsymbol{\eta}_{\mathbf{1}}+\boldsymbol{\beta}_{5} \mathbf{\eta}_{\mathbf{2}}+\boldsymbol{\beta}_{\mathbf{6}} \mathbf{\eta}_{3}+\boldsymbol{\zeta}_{4}
$$

(Kepatuhan $=0,157$ pemanfaatan pelayanan kesehatan $+0,273$ peran suami $+0,167$ persespsi $+0,215$ pemanfaatan pelayanan kesehatan $+0,188$ faktor lain)pada variabel kepatuhan dipengaruhi oleh peran bidan sebesar 0,157, dipengaruhi oleh peran suami sebesar 0,273, dipengaruhi oleh peran suami sebesar 0,167 dan dipengaruhi oleh pemanafaatan pelayanan kesehatan sebesar 0,215 dan sisanya dipengaruhi faktor lainsebesar 18,8\%.Berdasarkan persamaan matematis tersebut didapatkan bahwa variabel pemanfaatan pelayanan kesehatanyang paling besar pengaruh terhadap kepatuhan akseptor KB suntik ulang 1 bulan dengan nilai 0,408.

Untuk nilai Predictive relevance (nilai Q-square) adalah:

$$
\begin{aligned}
& \mathrm{Q}^{2}=1-\left(1-\mathrm{R}_{1}{ }^{2}\right)\left(1-\mathrm{R}_{2}{ }^{2}\right)\left(1-\mathrm{R}_{3}{ }^{2}\right)\left(1-\mathrm{R}_{4}{ }^{2}\right) \\
& =1-(1-0,516)(1-0,566)(1-0,807)(1-\quad 0,844) \\
& =1-(0,484)(0,434)(0,193)(0,156) \\
& =1-0,006 \\
& =0,99 \text { atau } 99,0 \%
\end{aligned}
$$

Nilai predictive relevance( $Q$ - Square) adalah 0,99

Galat model $=1-\mathrm{Q}^{2}$ 
Serambi Saintia

$$
\begin{aligned}
& =1-0,99 \\
& =0,01 \text { atau } 0,1 \%
\end{aligned}
$$

Hal tersebut menunjukkan model hasil analisis dapat menjelaskan 99,0\% keragaman data dan mampu mengkaji fenomena yang dipakai dalam penelitian, sedangkan $0,1 \%$ dijelaskan komponen lain yang tidak ada dalam penelitian ini.

\section{Pembahasan}

Pengaruh Peran Bidan terhadap Kepatuhan Akseptor KB Suntik Ulang 1 Bulan

Responden cenderung menganggap penting peran bidan dalam memberikan pelayanan kepada mereka, hasil pada penelitian ini menunjukkan bahwa responden menganggap peran bidan sudah cukup positif. Responden memperhatikan tingkah laku bidan ketika melakukan tugasnya sesuai dengan kompetensi yang dimiliki dan berdasarkan kebutuhan akseptor KB. Hasil penelitian menunjukkan bahwa peran bidan berpengaruh secara positif terhadap kepatuhan 0,15 dengan nilai T-statistik 30,9 dan signifikan pada $\alpha=5 \%$ yang artian berada di atas nilai kritis $(1,96)$. Peran bidan berpengaruh langsung dan tidak langsung terhadap kepatuhan. Pengaruh langsung sebesar 51,55\% dan berpengaruh tidak langsung sebesar 0,89\% dengan melalui jalur peran peran suami sebesar 0,718 (18\%), mempengaruhi pemanfaatan pelayanan kesehatan di BPM Sari Mulyani 0,046 (04,6\%), dan mempengaruhi persepsi sebesar $0,117(11,7 \%)$. Penelitian ini sesuai dengan teori yang ada yang menyatakan bahwa peran dari petugas kesehatan dapat merubah respon seorang ibu terhadap stressoryang lebih diterima sebelumnya (Magfiroh, 2010).

Dari ketiga indikator ukur yang dimiliki variabel peran bidan semuanya mampu menjelaskan variabel peran bidan, yaitu informasi, instrumental dan pelaksana. Pada penelitian ini didapatkan nilai $T$ statistic yang paling besar berada pada indikator instrumental 266,7 dengan demikian ketersediaan sarana dari bidan bisa membuat kepatuhan pada akseptor KB suntik sesuai jadwal. Pemanfaatan pelayanan kesehatan memberikan penyelesaian masalah yang merupakan suatu sumber dan pengakuan identitas individual, membimbing dan menengahi pemecahan suatu masalah, sebagai sumber dan validator identitas ibu dengan cara memberikan support, penghargaan, dan perhatian. Penelitian ini sejalan dengan penelitian Sustiaty (2008) yang mengatakan bahwa ada pengaruh antara peran bidan terhadap kepatuhan dengan nilai $p=0,002$ dengan OR peran bidan 7,005. Menurut peneliti dapat dianalisa bahwa peran bidan dengan ketiga indikatornya memiliki pengaruh yang positif terhadap kepatuhan, ini terbukti dari hasil penelitian bahwa responden merasa bahwa peran bidan sudah cukup baik dan berpengaruh positif terhadap mereka. Itu artinya jika kepatuhan akseptor KB suntik 1 bulan sesuai jadwal maka tidak akan terjadi kehamilan yang tidak diinginkan (Sustiaty, 2008).

\section{Pengaruh Peran Suami terhadap Kepatuhan Akseptor KB Suntik Ulang 1 Bulan}

Bentuk peran yang diberikan oleh suami kepada akseptor KB lebih mengendapkan sikap untuk saling berkomunikasi yang jujur dan terbuka dan sudah dimulai awal memakai KB suntik dan menemukan nilai-nilai penting dalam keluarga (Mannuba, 2011). Hasil penelitian menunjukkan bahwa peran suami berpengaruh secara positif terhadap kepatuhan akseptor KB suntik. Peran suami berpengaruh langsung dan tidak langsung terhadap kepatuhan. Peran suami berpengaruh langsung 


\section{Lia Muslima, dan Herjanti}

sebesar 23,8\% dan pengaruh tidak langsung sebesar 0,67\% melalui jalur peran bidan sebesar 0,719 (71,9\%). Penelitian ini sesuai dengan teori yang diungkapkan oleh Marcus (2013) yang menyatakan bahwa peran dari seorang suami ialah informasi verbal dannon verbal, saran, bantuan yang nyata yang diberikanoleh orang-orang yang akrab dengan subyek atau berupa kehadiran dan hal-hal yang dapat memberikan keuntungan emosional atau berpengaruh pada tingkah laku istri.

Perasaan cemas yang dirasakan ibu akan menurun dengan adanya peran serta suami Putu Prema (2012). Penelitian Masini (2015), bahwa suami harus memberikan perhatian kepada ibu dengan cara memberi kebebasan pada ibu untuk berpartisipasi dengan kelompoknya. Suami juga perlu memberikan dukungan penghargaan pada ibu seperti menciptakan rasa aman, lingkungan kondusif sehingga membuat ibu semangat dalam berKB. Suami perlu meningkatkan dukungan emosional pada ibu yaitu dengan memberikan semangat lewat kalimat pujian. Selain itu suami juga harus memberikan dukungan instrumental yaitu bantuan fisik kebutuhan ibu.

Dari ketiga indikator ukur yang dimiliki variabel peran suami semuanya mampu menjelaskan variabel peran suami, yaitu jalin komunikasi, dukungan finansial dan perhatian. Pada penelitian ini didaptkan nilai $T$ statistic yang paling besar berada pada indikator jalin komunikasi 50,10 jalin komunikasi dari peran suami dapat berupa untuk saling berkomunikasi yang jujur dan terbuka dan sudah dimulai awal memakai KB suntik dan menemukan nilai-nilai penting dalam keluarga. Hal ini dapat dilakukan melalui diskusi sehingga akseptor dapat melakukan kepatuhan terhadap jadwal KB. Hal yang sama dijelaskan Eka Sulistyorini (2007), bahwa peran serta suami mempengaruhi kecemasan sebesar $27,4 \%$. Semakin baik peran suami maka semakin menurunya kecemasan ibu.

Menurut peneliti dapat dianalisa bahwa peran suami dengan ketiga indikatornya memiliki pengaruh yang positif terhadap kepatuhan, dengan dukungan dari peran bidan yang baik, ini terbukti dari hasil penelitian bahwa responden merasa bahwa peran bidan sudah cukup baik dan berpengaruh langsung terhadap mereka.

\section{Pengaruh Persepsi terhadap Kepatuhan Akseptor KB Suntik Ulang 1 Bulan}

Suatu persepsi seseorang tidak akan muncul dengan sendirinya, akan tetapi melewati suatu proses dan faktor-faktor yang mempengaruhi terbentuknya suatu persepsi seseorang. Inilah yang menyebabkan pada setiap orang mempunyai perbedaan interpretasi satu sama lain, meskipun apa yang telah dilihatnya sama. Menurut Robinster dapat 3 faktor yang dapat mempengaruhi pembentukan persepsi seseorang, yaitu: individu yang bersangkutan (pemersepsi) atau perceiver, sasaran dari persepsi atau perceived dan situasi atau setting.

Hasil penelitian ini menunjukkan persepsi berpengaruh langsung terhadap kepatuhan sebesar 36,16\%. Persepsi juga berpengaruh positif terhadap kepatuhan0,160, dengan nilai T-statistik 14,67 dan signifikan pada $\alpha=5 \%$ yang artian berada di atas nilai kritis (1,96). Penelitian ini sejalan dengan teori yang diungkapkan oleh Walgito (2012) yang mengungkapkan bahwa persepsi merupakan suatu proses pengorganisasian, penginterpretasian terhadap stimulus yang diperoleh oleh organism atau individu sehingga membuat sesuatu yang berarti dan merupakan aktivitas yang integrated dalam diri individu. Respon sebagai akibat dari persepsi bisa diambil oleh individu dengan berbagai macam bentuk. Stimulus mana yang akan mendapatkan respon dari individu tergantung pada perhatian individu yang bersangkutan. Berdasarkan hal tersebut, 
perasaan, kemampuan berfikir, pengalaman-pengalaman yang dimiliki individu tidak sama, maka dalam mempersepsi sesuatu stimulus, hasil persepsi mungkin akan berbeda antar individu satu dengan individu lain.

Manusia secara umum menerima informasi dari lingkungan lewat proses yang sama oleh sebab itu dalam memahami persepsi harus ada proses dimana ada informasi yang didapatkan melalui memori organisme yang hidup. Fakta ini memudahkan peningkatan persepsi individu, adanya stimulus yang mempengaruhi individu yang menimbulkan suatu pengalaman dari organisme, sehingga muncul cara berpikir yang dalam, proses perceptual merupakan proses yang paling tinggi. Menurut Urva Susanti (2012) bahwa variabel persepsi mempunyai pengaruh yang positif terhadap variabel kepatuhan, ini terbukti dari hasil penelitian ini yang telah dilakukan, bahwa responden merasa bahwa persepsi mereka tentang kontrsepsi yang didorong oleh baiknya peran bidan dalam pemberian pelayanan dan dukungan positif dari suami.

\section{Pengaruh Pemanfaatan Pelayanan Kesehatan terhadap Kepatuhan Akseptor KB Suntik Ulang 1 Bulan}

Pelayanan kebidanan terintegrasi dengan pelayanan kesehatan. Selama ini pelayanan kesehatan bergantung pada sikap sosial masyarakat dan keadaan lingkungan tempat bidan bekerja. Kemajuan sosial ekonomi merupakan parameter yang terpenting dalam pelayanan kesehatan.

Didapatkan hasil bahwa pemanfaatan pelayanan kesehatan berpengaruh secara positif terhadap kepatuhan 0,40, dengan nilai T-statistik 9,98 maka signifikan pada $\alpha$ $=5 \%$ yang artian berada di atas nilai kritis $(1,96)$. Dari hasil pengaruh langsung pelayanan kebidanan terhadap kepatuhan sebesar $4,33 \%$ dan pengaruh tidak langsung sebesar $0,32 \%$ dengan melalui jalur peran bidan sebesar $0,125(12,5 \%)$.

Hasil penelitian ini juga mengungkap pelayanan kesehatan mempengaruhi persepsi ibu. Seperti diungkapkan Urva Susanti (2012), terdapat hubungan antara persepsi akseptor $\mathrm{KB}$ suntik tentang kontrasepsi $\mathrm{KB}$ dengan kecerdasan emosional. Hasil penelitian ini merekomendasikan tenaga kesehatan agar memotivasi akseptor KB memandang kontrasepsi KB sebagai hal yang positif.

Indikator dimensi pemanfaatan pelayanan kesehatan yang digunakan untuk menilai kualitas pelayanan agar terciptanya kepatuhan yang baik pada akseptor KB yaitu keterjangkauan tempat, permintaan (demand) dan keterjangkauan layanaan. Dari ketiga indikator tersebut dapat menjelaskan variabel pemanfaatan pelayanan kesehatan, akan tetapi hasil tertinggi diperolah pada indikator daya tanggap dengan $\mathrm{T}$ statistik 48,38 , yang artian keinginan para bidan membantu akseptor KB serta berkeinginan dan melaksanakan pemberian pelayanan dengan tanggap. Dimensi ini menekankan pada sikap yang penuh perhatian, cepat dan tepat dalam menghadapi permintaan, pertanyaan, keluhan, dan masalah yang sedang dialami akseptor KB. Dengan hal itu dapat menimbulkan mekanisme kepatuhan yang baik pada akseptor KB terhadap ketidak teraturan jadwalnya. Hermanto (2010) mengungkapkan keterkaitan indikator tersebut dengan pemanfaatan pelayanan kesehatan mempengaruhi persepsi ibu.

Menurut peneliti dapat dianalisa bahwa pemanfaatan pelayanan kesehatan dengan ketiga indikatornya memiliki pengaruh yang positif terhadap kepatuhan, dengan dorongan dari adanya peran bidan yang baik. ini terbukti dari hasil penelitian bahwa 
Lia Muslima, dan Herjanti

responden merasa bahwa pemanfaatan pelayanan kesehatan sudah cukup baik dan berpengaruh positif terhadap mereka.

\section{PENUTUP}

Dari penelitian ini dapat disimpulkan bahwa mencapai kepatuhan akseptor KB suntik yang baik diperlukan adanya peran bidan, peran suami, persepsi dan pemanfaatan pelayanan kesehatan yang baik. Variabel kepatuhan dipengaruhi oleh peran bidan, peran suami, persepsi dan pemanfaatan pelayanan kesehatan. Sehingga kepatuhan merupakan salah satu ukuran yang dapat digunakan dalam melihat peran bidan, peran bidan, peran suami, persepsi dan pemanfaatan pelayanan kesehatan.

\section{DAFTAR PUSTAKA}

Adriana Nara. Hubungan Pengetahuan, Sikap, Akses Pelayanan Kesehatan, Jumlah Sumber Informasi Dan Dukungan Keluarga Dengan Pemanfaatan Pelayanan Kesehatan Yang Memadai di Puskesmas Kawangu Kabupaten Sumba Timur Tahun 2013.

Aryani, 2010. Peran Bidan Dalam Konseling Awal Kontrasepsi Suntik Cyclofem di Puskesmas Mergangsan, Yogyakarta Tahun. 2012. Jurnal Ilmiah Kebidanan Akademi Kebidanan YLPP Purwokerto, Vol. 1 No. 1, Desember 2010.

BKKBN. Profil Hasil Pendataan Keluarga Tahun 2010. Jakarta

BKKBN, 2012a. Cukilan Data Program KB KN Nomor 246 ISSN : 0120-0197: Jakarta.

BKKBN. 2012b. Buku istilah bidang kependudukan KB keluarga Sejahtera: Jakarta. BKKBN.2013. Pelayanan Kontrasepsi : Jakarta BKKBN.

Eka Sulistyorini, 2007. Pengaruh Peran Serta Suami Terhadap Tingkat Kepatuhan Akseptor KB dalam Menjalani proses Kontrasepsi di Desa Jepat Lor Kecamatan Tayu Kabupaten Pati” Jurnal Berita Kedokteran Masyarakat. Vol XVI. 2007.

Hermanto, 2010. Pengaruh Persepsi Pemanfaatan Pelayanan Kesehatan Terhadap

Kepatuhan Pasien di BPM Soemarni Bulungan Kalimantan Timur” Jurnal Ilmiah Kebidanan Akademi Kebidanan YLPP Purwokerto, Vol. 1 No. 1, Desember 2010.

Kemenkes, 2013. Survei Demografi Kesehatan Indonesia.

Maghfiroh, 2010. Pengaruh Kehadiran Suami Terhadap kepatuhan Akseptor KB Suntik Ulang di BPS Ny. "Y” Kecamatan Cilimus Kabupaten Kuningan Tahun 2010.

Jurnal Ilmiah Kebidanan Akademi Kebidanan YLPP Purwokerto, Vol. 1 No. 1, Desember 2010.

Marcus, 2013. Panduan Lengkap Pelayanan KB Terkini Edisi kelima. Surakarta. Erlangga.

Masini, 2015. Pengaruh Kontrasepsi, Pekerjaan, Dukungan Suami, Dukungan Bidan/Tenaga Kesehatan Terhadap Partisipasi Ibu Dalam Kelas Ibu Hamil di Kabupaten Magelang”Jurnal Penelitian UNIB, Vol IX. No 2. Juli 2015. 109114.

Nursalam, 2011. Konsep dan penerapan Metodologi Penelitian Ilmu Keperawatan. Salemba: Medika. 
Putu Prema, 2012. Pengaruh Peran Suami Terhadap Istri Yang Mengalami Kecemasan Pada Kontrasepsi Di Kabupaten Gianyar" Jurnal Ilmiah Keperawatan STIKES Nani Hasanuddin Makassar, Vol. 1 No. 2 Tahun 2012.

Sustiaty, 2008. Pengaruh Antara Peran Suami Dan Peran Bidan Dan Kecemasan Dalam Menghadapi Kontrasepsi Terhadap Kepatuhan Pada Akseptor KB di Rumah Sakit Bersalin YK Madira Tahun 2008". Jurnal Ilmiah Kebidanan Akademi Kebidanan YLPP Purwokerto, Vol. 1 No. 1, Desember 2008.

Urva Susanti, 2012. Hubungan Persepsi Akseptor KB Tentang Kontrasepsi Dengan Tingkat Kecerdasan Emosional di Puskesmas Umban Sari Kecamatan Rumbai” Jurnal Berita Kedokteran Masyarakat. Vol XVI.2012

Walgito, 2012. Buku Panduan Praktis Persepsi Pelayanan Kontrasepsi. YBP-SP. Jakarta. 